\title{
The Problem of the Body and Corporality of the Modern Man in Cinematography
}

\author{
Larisa S. Kovaleva* \\ Khabarovsk State Institute of Culture \\ 112 Krasnorechenskaia Str., Khabarovsk, 680045, Russia
}

Received 24.01.2016, received in revised form 10.03.2016, accepted 24.04.2016

\begin{abstract}
Each epoch has its own understanding and vision of the problem of the body and corporality. This article attempts to considersuch concepts as "body" and "corporality" through the prism of the cinematography, the way they are presented in the selected films. Man has ceased to be considered as an integral structure in the modern world. The body has ceased to be an individual and "private matter". It is put on show. Corporality, on the contrary, is hidden by the modern society, giving a surrogate for everyone instead. The personality ofthe human in this situation is changing, and mostly in a negative way. These problem reflected in modern cinema. In this research the films by David Fincher ("Fight Club"), Mary Herron ("American Psycho") and David Cronenberg ("Videodrome", "Existenz") have been analyzed. The problem of the body and corporalityis considered through the analysis ofsplittingof personality of the main characters and the surrounding world.
\end{abstract}

Keywords: body, corporality, cinematography, modern culture, mass culture.

DOI: 10.17516/1997-1370-2016-9-6-1466-1473.

Research area: culture studies.

\section{Introduction}

The category of corporality was introduced into modern science under the influence of cultural studies and semiotics, when it was discovered that the human body is understood differently in different cultures. Such natural biological concepts as "pain", "illness", etc., within the framework of culture appeared to be mot so much the natural state of the body, but cultural and mental concepts formed by the human.

At all times, people have paid attention to their body, but today it has become the most topical problem. We can say that almost all fields of science are studying the problem of the human body: medicine, anthropology, biomechanics, psychology, etc. At the same time, the modern science cannot give a clear answer what the body and corporalityare.The relevance of the problem of understanding the phenomenon of the human body is proved by:

- worsening of health problems. This is most relevant for the living conditions in large cities. Increased nervousness, mental disorders, cardiovascular, allergic, asthmatic diseases, drug and alcohol addiction and other problems have become daily companions of urbanization;

- increasing value of human personality in the modern world and sharpened perception

(c) Siberian Federal University. All rights reserved

* Corresponding author E-mail address: haoma8@yandex.ru 
of everything connected with personal selfexpression, and the body is one such means;

- aggravation of the problems of sexual behaviour and sexual culture in the conditions of the modern civilization. Eroticism has long ceased to be an element of privacy, "a personal matter". The media andadvertising make it obsessive and aggressive;

- issues related to euthanasia, reproductive technologies, abortion, cloning, organ transplantation, medical legislation;

- perception of the body as the carrier of symbolic value in the conditions of the modern civilization. New social groups and youth formations: homosexuals, punks, bikers, skinheads, rappers, skateboarders, skaters, diggers, nudists and others seeking to assert their status and external attributes;

- increased importance of the issues of image as the ability to present oneself to a customer, employer, voter as being in the healthystate of mind and bodyin the conditions of the consumer society.

As E.V.Savelova notes, "the $20^{\text {th }}$ century is marked by fundamental changes in relation to corporality as a phenomenon of culture. The human body from the peripheral, marginal areas of social and cultural space moves into the spotlight and becomes the point of reference in determining ontological foundations of existence of both a personality and culture as a whole" (Savelova, 2014, 26).

\section{Theoretical framework}

The research tradition usually separates such concepts as "body" and "corporality". Epistemological studies consider the body as the structure of the sensory organs of the human, the source of their direct sensations. Usually the term "body" means a physical object, an organism of a human or an animal without subjectivity and spirituality. P.D. Tishchenkoin "Novaia filosofskaia entsiklopediia" (New Encyclopedia of Philosophy) notes that the presence of the concept "body" in the culture "witnesses presence of categorization of existence into 'external' and 'internal', something that is open (revealed) in things and the person, and something that is hidden, the sphere of ideal essences, etc." (Stepin, 2001, 28).

In addition to the "normal", natural human body there is another one determined, since the human is included not only in the world of external things opposed to him by nature, but also into the social, human environment, which like the natural environment, has its own restrictions and laws.

According to A. Tkhostov, the mother from early childhood teachesthe child to properly observe a whole number of rules related to the diet, rewards and punishment, assigning of responsibility and guilt, etc. In fact, she creates a set of resistances which generate the configuration ofthe "cultural body" (Tkhostov).

In modern philosophy, especially in the framework of post-modernism, the body is as a rule interpreted as"the universal stabilizing structure of a unified human experience. The body is initial in relation to natural and cultural objects, thanks to it they exist. P. Valery mention sin his classification: "my" body, the body "which is visible to others"; the body which "embodies us", holds the physical unity and connects various images, but that cannot be thought of and implemented by itself" (Stepin, 2001).

M.M. Bakhtin distinguished between the "internal" and "external" body. "The internal body is my body as a moment of my consciousness, it is a collection of domestic inner feelings, needs and desires, united around the inner world" (Bakhtin, 1979).

Bergson wrote that the body always fills our consciousness or the consciousness fills the body. Their interrelation does not allow the 
consciousness to completely separate from the body in its actions and there is always the inner voice of the body. The body is connected with existence, and for the living person to have the body means to grow into a certain environment, to blend together with certain projects, and continuously deepen into them. Therefore, the body must be seen not as an object of the world, but as a means of communication with it (Bergson, 2001).

Thus, it turns out that "corporality"is the picture of our consciousness, of what a person is. The human body throughout its life is constantly changing, respectively, forming new corporality, new consciousness and a new personality

"Corporality is a term used for fixing various states of the biological human body under the influence of social and mental factors" (Gritsanov, 2007).

\section{Discussion}

It is well known that in any historical period the formation of corporalityas a sociocultural phenomenon occurred as aresult of influence of such socialand cultural factor son the biological human body as economy and politics, way of life of different layers of the society, actions of social institutes, religion and philosophy, etc. Therefore, for each historical period and culture its own perception of human corporality is typical.

This article considers the issues of corporality of the modern human through the prism of cinematography.

The movie "Fight Club" directed by David Fincher (1999) takes place in our contemporary era of consumption. The modern man no longer thinks about the problem of shelter, food and security. His only care is what new and unusual can be offered by the world in order to meet his consuming needs. If we turn to the film, we can see at the very beginning how Edward Norton's character talks about the need to buy new covers for the furniture that would perfectly match his new environmentally friendly furniture set. This problem takes up all his time and all his thoughts. It seems that there is nothing more important in his personal life than the concern of choosing and buying a new table or clothes. The hero of Edward Norton is a typical average man of our time, and he would not be of interest to our research, if there was not one "but": he suffers from insomnia.

It is known that insomnia is the state of unsatisfactory duration and/or poor quality of sleep for a considerable period of time. It can be assumed that it is the way his "inner body"reminds him about itself. In the mind of a person thereare "the image of my body for me" and "the image of my body for the others" (Bergson, 2001). A healthy person is the one where these two concepts coexist peacefully and cooperate. We can assume that throughout the life of E. Norton'shero, "the image of my body for the others" had a very strong influence on his personality, and his corporality, while "the image of my body for me"was basically neglected. This conclusion can be drawn from the fact that the protagonist-narrator is not an ordinary mass man aimed at consumption. He has a rather interesting way of thinking: the scene on the plane is a proof. He has just fallen into the modern culturetrap, when the human bodyis exposed to the utmost. The modern society recognizes only the body, its sexuality, its needs and improvement with the help of external tools. The problems with the sense of one's own corporalityare proved by the following moment in the film: the narrator joins a support group. Just seeing real genuine emotions of people and even feeling them himself, he feels not only his physical body, but also the internal one. It is this moment, when the silhouette of Tyler begins to appear.

We can say that the hero of Brad Pitt Tyler Durden - is the image of corporalityof E. Norton'shero that is visible to us. He is what 
the narrator has always wanted to be. Tyler is a revoltof human corporality against the modern culture, we can say that he is the revolt against the body. At the same time, Tyler is aggressive to everything that surrounds him. In our opinion, this moment is interesting due to the fact that the modern culture is characterized by an aggravation of sexual problems and actual human sexuality. What was once a private life and a "private matter"is now displayed for the public by the media and advertising. Thus, Tyler is the personification of the most intimate part, the private life of a person, but at the same time, he is extremely aggressive, because this is what the modern culture requires.

Tyler Durden destroys the familiar environment of the narrator. In the film, these are the moments when the narrator loses his luggage with all his clothes, and the explosion of the apartment. Thus, the hero of E. Norton has lost everything, he has been left alone with himself. That is, at this moment he has lost the connection with the modern consumer society, and for the first time he was able to see himself not as a physical body involved in the process of consumption, but as an individual unique personality. It is the moment when he called Tyler when the narrator turned to his corporality.

After the destruction of familiar environment, the narrator enters a different world of our contemporary reality. Tyler gave the hero of E. Norton a new home devoid of the usual benefits typical forthe civilization of consumption. There is no TV, no beds and sofas, wardrobes and tables, there are only dirty, moldy mattresses, shabby walls and the ceiling ready to collapse at any moment. This new home is surrounded by industrial buildings only, so that the viewer sometimes gets the feeling that it is some other world.

Tyler has also shown the narrator the world of true emotions. He makes him feel real, almost animal pain. It is well demonstrated, in our opinion, in the episode in which the narrator makes a chemical burn on his hand. Tyler makes him forget about the artificial sense of security and gives the feeling of a constant struggle for the existence. Thus, thanks to the emergence of Tyler, the narrator has realized his identity, hiscorporality.

"Fight Club" is a film about the revolt of corporality of the modern man. The revolt begins when Tyler starts to help others "to free" their corporality. He opens a fight club, where each inhabitant can experience the true nature of human emotions: pain, fear, happiness, excitement, etc. These feelings have not been retouched by the TV and advertising. In the fight club,everyone gains their corporality, but beforethat they destroy their environment and their bodies. In the film, there is a moment when the narrator talks about the new members of the club. When they come to the club, their bodies are loose and weak. But months later, their bodies grow stronger and become modified. They are coveredwith cuts and bruises. Their bodies are simply "crying out loud" about their own individuality. They get out of the world, they attract attention, they create a new image of the human.

The film“American Psycho" (2000) directed by Mary Herron demonstrates the same problem of the body and corporality.

In the film "American Psycho", the protagonist is the exact opposite of the protagonist of "Fight Club".

Patrick Bateman is a successful man, vice-president of a company. He is young, rich, healthy and handsome. He has a perfect body and is always dressed in a perfect costume. He is the ideal person that almost everyone in today's world want to look like. There is only one "but": he is a sadist and a psychopath.

Patrick Bateman is surrounded by people who have meaningless conversations every day. 
For them, the whole society is divided into two types:cool people who wear expensive suits of famous brands, and losers who wear cheap clothes. They boast to each other of their business cards and stories about how they were able to dine at the most expensive and fancy restaurant. Their idleness and boredom makes them consume drugs and antidepressants. They are not even able to distinguish one person from another, because all of them wear the same clothes.This is highlighted by the scene in the film where they unsuccessfully try to recall the name of one of their friends.And the protagonist is the same as his friends: a faceless, eternally bored person. $\mathrm{He}$ changes only at nightfall.

An interesting fact is that the two main characters in the films "Fight Club" and "American Psycho" show their true colours only at dusk. Both are experiencing the true feelings only at this time. Edward Norton's hero goes to support groups in the evenings, and Christian Bale's hero kills people. Both characters have a problem with a sense of their corporality. More over, there is a similar trend for both heroes that their corporalityis revealing aggressively.

Patrick Bateman is the image of a man whose body and corporality are very far from each other. Like in "Fight Club", the audience feels that they see two different people. There is a moment in the film that makes the viewer question whetherit was Patrick who committed all the murders. It seems as if it was somebody else. This is perhaps the main tragedy of the hero: for his whole life he was playing somebody else's role, a kind of a model of a person that he had received from the modern culture. He was only taking care of his body, his appearance. At the same time he was not developing his inner spiritual needs. As a result, his corporalityhas mutated to such an extent that it is trying to destroy the whole environment of the protagonist. Basically, hisvictims were people from his circle of friends, the same people as he was. We may say that each time he was killing them, he was killing himself, destroying his hated body.

A similar situation occurs with the main character in David Cronenberg's "Videodrome" (1982). The President of the $83^{\text {rd }}$ channel Max Rennes is looking for the opportunity to raise the rating of his channel. His station stumbles upon a signal of the channel called "Videodrome" constantly broadcasting violence and torture. Max Rennes quickly realizes that these videos raise the rating of his channel and tries to find the creators of the show.

The main character in his search for the creators of "Videodrome"enters a completely different world: the world of fantasy. He finds himself on the other side of the television screen. At some point Max Rennes, as well as the viewer, ceases to understand what is real and what is a figment of his imagination.

In the course of the film Max Rennes's body undergoes some changes. Once he learns that "Videodrome" is transmitted through videotapes, then the soon turns into an appendage of the VCR. In his belly, there is a hole for the videotape and he becomes a kind of a video player.

The film "Videodrome" is set in the period of time when there was a view that a person could get seriously ill from continuous watching of TV, could get exposed to radiation and get cancer. In our opinion, the film looks like a reference to this delusion. The protagonist spends all his time near the screen, it's his job. Everything he does is somehow related to the TV show production. We can assume that like the previous two characters, the body and corporality of Max Rennes are in a kind of a conflict. If the two previous directors showed the audience the life of the protagonist, his thoughts, feelings and environment, the protagonist of "Videodrome" does not have it. It seems that he did not exist prior to the events shown in the film. It is unclear whether this man 
really existed or he is the product of the next show. Only one fact is well known: that at some point his body starts to mutate. He turns into a living VCR, and then merges with a television screen, his hands turn into weapons. One thing is clear, his mind does not control the body. His body is rebelling, it's trying to kill itself and all that surrounds it. Patrick Bateman and Max Rennes are alike to some extent. We may even assume that they could have been one character as a reflection of what the modern society and culture make to the man and his body.

It is worth noting that the director David Cronenbergoften shows changes of mental and physiological states of the manin his films. The film "Existenz" (1999) also touches upon the problem of the body and corporality. As in "Videodrome", the film is set at the border of the real world and the world of fantasy (in this case, the virtual one).

The film shows the world where everyone is playing virtual games. The action begins at the moment of presentation of the new game "Existenz". Its main feature is that it is almost impossible to distinguish it from the real world. Here, the player does not differ from the character of the game. The sensation of pain is the same as in the real world. Players who are in the game need to eat and sleep.

The player's connection to the world of "Existenz" is quite interesting. It is a special device which is a living organic being. It is connectedto the human body and attaches it to the game. Thus, in this film, the human body is presented as an item, a biological machine which is a guide tothe virtual reality.

In the film"Existenz", human corporality is separated from the body. The body is an abandoned object in the real world, it is only needed to connect to the game. As for the humans, their thoughts, feelings and experiences live separately in a kind of virtual reality. Virtual reality gives them a new body, which ever they want. We can assume that in this film, thestruggle of the body or corporality is not so violent as in the previously considered films due to the fact that the characters of "Existenz" can choose on their own what they want to be. There is no need to adapt to the needs of the surrounding world. They choose the world in which to live and a role in it. This is well emphasized by the end of the film, when the main characters are changing their rolesto the absolutely opposite ones. That is, a person has an opportunity to live several lives. Thanks to virtual reality, he achieves the unity of the body and corporality, but at the same time, his body and corporality are incredibly far from each other.

\section{Conclusion}

The films analyzed in this study show typicals plitting of personality of the main characters. Each of them represent two people sharing one body. The world is also split apart: the real world and the virtual one. In "Fight Club", there are two worlds, the world of the club and the world beyond the club. In "American Psycho", there is a world of luxury and success, where only brands matter, and the world of poverty, which is in decline. "Videodrome" and "Existenz" show the real world and the world of some kind of virtual reality. Correspondingly, the main characters live in two worlds. The duality of the world and the protagonist highlight that in the modern world the human has ceased to be an integral personality. He exists in the world where the society imposes it srules of be haviour and appearance. These rules may change so quickly though, that the person may not be able to adapt to the new requirements. For modern culture, the sense of irreality of what is happening is very typical. The modern man like the protagonists of the films considered herewith has ceased to understand where is his 
real life, and where is the virtual one. Therefore, the conflict of the body and corporality of the human is more acute than ever. Corporality is the inner world of each human. It's what makes us unique. It is the world of true feelings and emotions. As the same time, corporality is our dark subconscious, which can destroy the human and his world.

\section{References}

Bakhtin, M.M. (1979). Estetika slovesnogo tvorchestva [Esthetics of the written word]. Moscow, Khudozhestvennaia literature, $59 \mathrm{p}$.

Bergson, A. (2001). Tvorcheskaia evoliutsiia [Creative evolution]. Moscow, 269 p.

Bugueva, N.A. (2015). Telesnost' cheloveka kak sotsiokul'turnyi fenomen [Corporality of the human as a sociocultural phenomenon]. Available at: http://www.lib.csu.ru/vch/094/66.pdf (accessed 8 May 2015)

Gritsanov, A.A. (2007). Novyi filosofskii slovar'. Postmodernizm.[New Philosophical Dictionary. Postmodernism]. Minsk, $651 \mathrm{p}$.

Levita, S. (2007). Kul'turologiia. Entsiklopediia [Culturology. Encyclopedia]. Moscow, 660 p.

Savelova, E.V. (2014). Problema telesnosti v krizisnom prostranstve sovremennoi kul'tury [The problem of corporality in the crisis space of modern culture]. In Izvestiia Volgogradskogo gosudarstvennogo pedagogicheskogo universiteta. Seriia 'Sotsial'no-ekonomicheskie nauki i iskusstvo' [News of Volgograd State Pedagogical University. Series 'Socio-economic Sciences and Art']. 8 (93), 26-31.

Stepin, V.S. (2001). Novaia filosofskaia entsiklopediia [New Encyclopedia of Philosophy]. Moscow, $330 \mathrm{p}$.

Tkhostov, A. Sh. (2002). Psikhologiia telestnosti [Psychology of corporality]. Available at: http:// www.gumer.info/bibliotek_Buks/Psihol/thost/04.php (accessed 14 May 2015)

\section{Проблема тела и телесности современного человека}

\section{в кинематографе}

Л.С. Ковалева

Хабаровский государственный институт культуры Россия, 680045, Хабаровск, ул. Краснореченская, 112

Каждая эпоха имеет свое понимание и видение проблемы тела и телесности. В данной статье делается попытка рассмотреть через призму произведений кинематографа значение таких понятий, как «тело» и «телесность», их отображение в выбранных кинофильмах. Человек перестал рассматриваться в современном мире как целостная структура. Тело перестало быть индивидуальным и «личным делом». Оно выставляется напоказ. Телесность же, наоборот, современное общество прячет и дает каждому человеку некий суррогат. Личность человека в такой ситуации претерпевает изменения, и в основном негативные. Отражение этой проблематики можно наблюдать в современном кинематографе. В исследовании были использованы фильмы Дэвида Финчера («Бойцовский клуб»), Мэри Херрон («Американский психопат»), Дэвида Кроненберга («Видеодром», «Экзистенция»). Проблема 
тела и телесности рассматривается путем анализа расщепления личности главных героев и окружающего мира.

Ключевые слова: тело, телесность, кинематограф, современная культура, массовая культура.

Научная спецчиальность: 24.00.00 - культурология. 